\title{
Brokeback Mountain
}




\section{American Indies}

Series Editors: Gary Needham and Yannis Tzioumakis

Titles in the series include:

The Spanish Prisoner

Yannis Tzioumakis

9780748633685 (hbk)

9780748633692 (pbk)

Brokeback Mountain

Gary Needham

9780748633821 (hbk)

9780748633838 (pbk)

\section{Memento}

Claire Molloy

9780748637713 (hbk)

9780748637720 (pbk)

\section{Lost in Translation}

Geoff King

9780748637454 (hbk)

9780748637461 (pbk)

Forthcoming titles include:

Far From Heaven

Glyn Davis

9780748637782 (hbk)

9780748637799 (pbk) 


\section{Brokeback Mountain}

Gary Needham

Edinburgh University Press 
(C) Gary Needham, 2010

Illustrations appear courtesy of the following copyright holders:

Focus Features (Figures 1, 2, 6-11); United Artists/MGM (Figure 3);

AMG (Figure 4); Kino Video (Figure 5)

Edinburgh University Press Ltd

22 George Square, Edinburgh

www.euppublishing.com

Typeset in 11/13pt Monotype Baskerville by Servis Filmsetting Ltd, Stockport, Cheshire, and printed and bound by CPI Antony Rowe, Chippenham and Eastbourne

A CIP record for this book is available from the British Library

ISBN 9780748633821 (hardback)

ISBN 9780748633838 (paperback)

The right of Gary Needham

to be identified as author of this work

has been asserted in accordance with

the Copyright, Designs and Patents Act 1988. 